\title{
Pengaruh Kompetensi, Obyektivitas, dan Pengalaman Kerja Terhadap Kualitas Hasil Audit pada Perwakilan BPKP Provinsi Sulawesi Utara
}

\author{
KUKUH HARYOKO ${ }^{1}$, GRACE B. NANGOI ${ }^{2}$, LINTJE KALANGI $^{3}$
}

\author{
1,2,3Program Magister Akutansi, Fakultas Ekonomi dan Bisnis Universitas Sam Ratulangi
} email: kukuhharyoko@gmail.com

\begin{abstract}
The effective role of the Government Internal Auditor (APIP) can be realized if supported by a professional and competent Auditor with an increasingly qualified internal audit result. In order to implement the results of quality internal audi, it requires a quality measure in accordance with the mandate of assignment of each APIP. This research aims to identify the influences of competence, objectivity and job experience towards quality of audit results at The Financial and Development Supervisory Board (BPKP) Representative of North Sulawesi Province. Respondents are auditors who work in BPKP Representative North Sulawesi Province. There were 76 respondents. This study used primary data. Data were collected by questionnaires. The results show that the coefficient of determination is 0.620 . It means $62 \%$ audit quality is influenced by competency, objectivity, and job experience. On the other hand, the remaining of $38 \%$ is influenced by other factors beyond this study. Partially hypothesis test ( $t$ test) was conducted in order to know the influence of each independent variable individually towards the dependent variable. The analysis result shows that competency, objectivity and job experience have positively significant influences towards quality of audit result.
\end{abstract}

Keywords: competency, objectivity, job experience, and quality of audit result.

Abstrak. Peran Aparat Pengawas Internal Pemerintah (APIP) yang efektif dapat terwujud jika didukung dengan auditor yang profesional dan kompeten dengan hasil audit intern yang semakin berkualitas. Dalam rangka mewujudkan hasil audit intern yang berkualitas diperlukan suatu ukuran mutu yang sesuai dengan mandat penugasan masing-masing APIP. Penelitian ini bertujuan untuk menganalisis pengaruh kompetensi, obyektivitas dan pengalaman kerja terhadap kualitas hasil audit pada Perwakilan Badan Pengawasan Keuangan dan Pembangunan (BPKP) Provinsi Sulawesi Utara.Responden dalam penelitian adalah auditor yang bekerja di Perwakilan BPKP Provinsi Sulawesi Utara.Jumlah responde adalah 76 auditor.Jenis data yang digunakan dalam penelitian ini adalah data primer.Pengumpulan data dilakukan dengan kuesioner.Hasil penelitian berdasarkan perhitungan koefisien determinasi dalam penelitian ini adalah 0,620 artinya kualitas hasil audit sebesar $62 \%$ dipengaruhi oleh kompetensi, obyektivitas dan pengalaman kerja. Sedangkan sisanya 38\% dipengaruhi oleh faktor lain di luar penelitian ini. Pengujian hipotesis secara parsial dilakukan melalui uji t untuk mengetahui besarnya pengaruh masing-masing variabel independen secara individual terhadap variabel dependen. Hasil analisis menunjukkan bahwa kompetensi, obyektivitas dan pengalaman kerja, memiliki pengaruh positif dan signifikan terhadap terhadap kualitas hasil audit.

Kata kunci: kompetensi, obyektivitas, pengalaman kerja, dan kualitas hasil audit.

\section{Pendahuluan}

Salah satu upaya yang dilakukan pemerintah dalam rangka meningkatkan transparansi dan akuntabilitas pengelolaan keuangan negara adalah dengan ditetapkannya paket undang-undang tentang keuangan negara, yaitu Undang-undang (UU) nomor 17 tahun 2003 tentang Keuangan Negara dan UU nomor 01 tahun 2004 tentang Perbendaharaan Negara, serta UU nomor 15 tahun 2004 tentang Pemeriksaan Pengelolaan dan Tanggung Jawab Keuangan Negara. Upaya konkrit untuk mewujudkan transparansi dan akuntabilitas pengelolaan keuangan Negara, salah satunya adalah penyampaian laporan pertanggungjawaban keuangan pemerintah yang memenuhi prinsip-prinsip tepat waktu dan disusun dengan mengikuti Standar Akuntansi Pemerintahan (SAP) yang telah diterima secara umum.

Pada tahun 2005 Pemerintah menetapkan Peraturan Pemerintah (PP) Nomor 24 tahun 2005 tentang Standar Akuntansi Pemerintahan. Dalam perkembangannya, PP no 24 tahun 2005 diperbaharui menjadi PP Nomor 71 tahun 2010.Standar ini dibutuhkan dalam rangka penyusunan laporan pertanggungjawaban pelaksanaan APBN/APBD. Pada tahun 2008 Pemerintah menetapkan Peraturan Pemerintah (PP) yang mengatur Sistem Pengendalian Intern Pemerintah yaitu PP nomor 60 tahun 2008 tentang Sistem Pengendalian Intern Pemerintah (SPIP).

Untuk meningkatkan kualitas transparansi dan akuntabilitas laporan keuangan pemerintah daerah maka laporan keuangan perlu diaudit oleh lembaga yang menjalankan fungsi audit baik itu bersifat internal maupun eksternal bagi Pemerintah Pusat, Kementerian/Lembaga, Pemerintah Daerah, dan semua Intansi Pemerintah baik Instansi terkait pelaksanaan fungsi Kementerian/Lembaga di Daerah (Instansi Pusat/Vertikal), maupun Instansi di bawah struktur Pemerintah Daerah.

Audit internal mendorong terciptanya sistem pemerintahan yang bersih dan baik, terutama dalam pengelolaan keuangannya.Di dalam pemerintahan, peran audit internal dilaksanakan oleh Aparat Pengawasan Intern Pemerintah (APIP). Peran APIP yang efektif dapat terwujud jika didukung dengan Auditor yang profesional dan kompeten dengan hasil audit intern yang semakin berkualitas. Dalam rangka mewujudkan hasil 
audit intern yang berkualitas diperlukan suatu ukuran mutu yang sesuai dengan mandat penugasan masingmasing APIP.

Dalam melaksanakan tugas dan wewenangnya, auditor internal tersebut dituntut bekerja dengan baik, teliti dan professional agar didapatkan hasil kerja yang memuaskan dari auditor.Kualitas hasil kerja atau kinerja adalah sesuatu yang dicapai, prestasi yang diperlihatkan dan kemampuan menjalankan tugas dengan baik dan tepat. Bagi auditor kualitas hasil kerja atau kinerja dapat dinilai dari kualitas audit yang dihasilkan.

Pentingnya kompetensi, obyektivitas dan pengalaman kerja auditor untuk meningkatkan kualitas hasil kerja atau kinerja auditor diatur dalam standar auditing. Penugasan audit intern harus dilakukan dengan kompetensi dan obyektif. Standar Audit Intern Pemerintah Indonesia menyatakan Auditor harus memiliki pendidikan, pengetahuan, keahlian dan keterampilan, pengalaman, serta kompetensi lain yang dibutuhkan untuk melaksanakan tanggung jawabnya. Pendidikan, pengetahuan, keahlian dan keterampilan, pengalaman, serta kompetensi lain adalah bersifat kolektif yang mengacu pada kemampuan profesional yang diperlukan auditor untuk secara efektif melaksanakan tanggung jawab profesionalnya. Auditor harus memiliki sikap yang netral dan tidak bias serta menghindari konflik kepentingan dalam merencanakan, melaksanakan, dan melaporkan penugasan yang dilakukannya. Pengalaman merupakan akumulasi gabungan dari semua yang diperoleh melalui berhadapan dan berinteraksi secara berulang-ulang dengan sesama benda alam, keadaan, gagasan, dan penginderaan

Peraturan Presiden Republik Indonesia Nomor 192 Tahun 2014 menyatakan bahwa Badan Pengawasan Keuangan dan Pembangunan, selanjutnya disingkat BPKP, merupakan aparat pengawasan intern pemerintah. BPKP berada di bawah dan bertanggung jawab kepada Presiden.BPKP dipimpin oleh seorang Kepala.BPKP mempunyai tugas menyelenggarakan urusan pemerintahan di bidang pengawasan keuangan negara/ daerah dan pembangunan nasional.

Untuk menyelenggarakan tugas dan fungsi BPKP di daerah, dibentuk Kantor Perwakilan BPKP di setiap Provinsi.Perwakilan BPKP Provinsi Sulawesi Utara merupakan menyelenggarakan tugas dan fungsi BPKP di Provinsi Sulawesi Utara.Perwakilan BPKP Provinsi Sulawesi Utara dipimpin oleh Kepala Perwakilan yang bertanggung jawab kepada Kepala.

Dari hasil temuan atas kegiatan pengawasan yang dilakukan oleh Perwakilan BPKP Provinsi Sulawesi Utara selang 5 (lima) tahun terakhir, sebagian sudah ditindaklanjuti. Namun apabila dilihat sisa temuan, masih menunjukkan banyak temuan yang belum ditindaklanjuti.

Berdasarkan laporan hasil evaluasi penyelenggaraan SPIP (penilaian tingkat maturitas) disimpulkan bahwa penyelenggaraan SPIP pada Perwakilan BPKP Provinsi Sulawesi Utara tahun 2016 berada pada level "terdefinisi" atau tingkat 3 dari 6 tingkat maturitas SPIP.

Pendidikan dan pelatihan fungsional di bidang pengawasan yang belum berjalan dengan baik.Hal tersebut tercermin dari komposisi jumlah auditor muda yang masih dirasa sangat kurang. Auditor muda berfungsi sebagai ketua tim. Dengan jumlah total auditor sebanyak 81 orang, jumlah auditor muda sebanyak 9 orang masih dirasa sangat kurang. Akibatnya dalam penugasan banyak auditor yang sebenarnya belum berserfitikat auditor muda (ketua tim) namun diperankan/difungsikan sebagai ketua tim.

Hal yang mungkin mempengaruhi yaitu wilayah Sulawesi Utara yang tidak terlalu besar akan memungkinkan objek yang diaudit cenderung berulang-ulang dan ini akan menimbulkan kerawanan atas objektifitas auditor Perwakilan BPKP Provinsi Sulawesi Utara. Belum lagi fasilitas yang disediakan obyek pemeriksaan selama penugasan, dapat mempengaruhi obyektivitas auditor Perwakilan BPKP Provinsi Sulawesi Utara.

Harahap (2015) dan Sukriah dkk. (2009) mengemukakan bahwa kompetensi berpengaruh positif terhadap kualitas audit. Hal tersebut diartikan bahwa semakin tinggi kompetensi auditor, akan semakin baik kualitas hasil pemeriksaannya. Hal ini sejalan dengan penelitian Furiady dan Kurnia (2015) dan Bouhawia dkk.(2015), namun tidak sejalan dengan penelitan Kovinna dan Betri (2014) yang menyatakan kompetensi tidak berpengaruh signifikan terhadap kulaitas hasil audit.

Ilat dkk.(2015) menyatakan obyektivitas pada auditor berpengaruh terhadap kualitas hasil audit.Penelitian yang dilakukan oleh Mabruri dan Winarna (2010), menyatakan semakin tinggi obyektifitas auditor, maka semakin baik kualitas auditnya.Hasil penelitian ini sejalan dengan penelitian dari Sukriah (2009), Harahap (2014), dan Furiady dan Kurnia (2015) yang menyatakan ada pengaruh positif obyektivitas auditor terhadap kualitas audit.

Terkait dengan pengalaman kerja, hasil analisis data dan pengujian hipotesis Ilat dkk.(2015), memperlihatkan bahwa pengalaman kerja berpengaruh signifikan terhadap kualitas hasil audit pada auditor, namun mempunyai korelasi yang negatif.Penelitian Sukriah dkk. (2009) menunjukkan bahwa pengalaman kerja berpengaruh positif terhadap kualitas hasil pemeriksaan, sejalan dengan penilitan Mabruri dan Winarna (2010), Wandita dkk.(2014), Bouhawia dkk. (2015) dan Usman (2016). Hal ini tidak sejalan dengan penelitian Furiady dan Kurnia (2015) dan Kovinna dan Betri (2014) yang menyatakan pengalaman kerja tidak berpengaruh pada kualitas hasil audit.

Penelitian ini mempunyai tujuan untuk menganalisis dan mendapatkan bukti empiris tentang:

1) Pengaruh kompetensi terhadap kualitas hasil audit;

2) Pengaruh obyektivitas terhadap kualitas hasil audit; dan 
3) Pengaruh pengalaman kerja terhadap kualitas hasil audit, yang dirumuskan dalam kerangka konseptual sebagaimana pada gambar 1 .

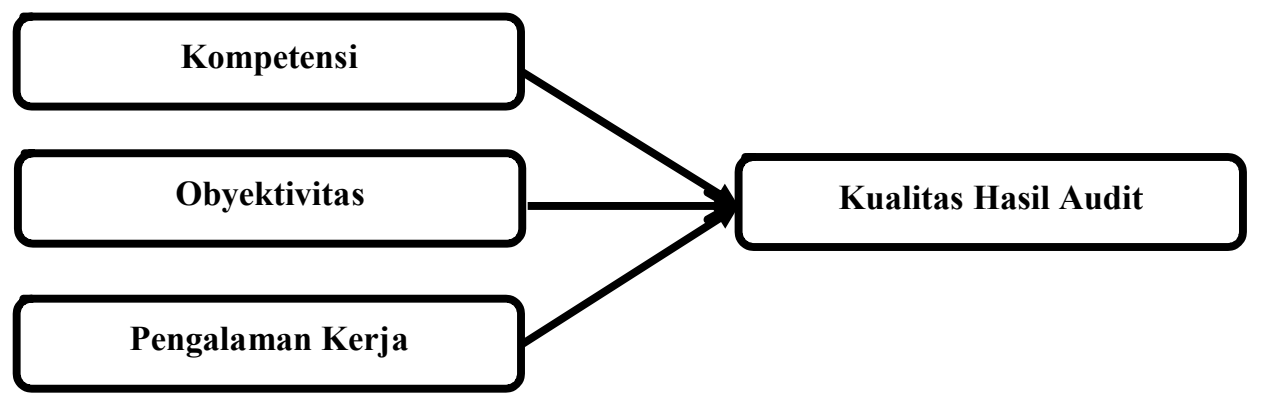

Gambar 1. Kerangka Konseptual

Kompetensi auditor adalah kualifikasi yang dibutuhkan oleh auditor untuk melaksanakan audit dengan benar (Rai, 2008). Dalam melakukan audit, seorang auditor harus memiliki mutu personal yang baik, pengetahuan yang memadai, serta keahlian khusus di bidangnya.Kompetensi berkaitan dengan keahlian profesional yang dimiliki oleh auditor sebagai hasil dari pendidikan formal, ujian profesional maupun keikutsertaan dalam pelatihan, seminar, simposium. Kompetensi adalah keseluruhan pengetahuan, kemampuan/keterampilan dan sikap kerja ditambah atribut kepribadian yang dimiliki oleh seseorang yang mencakup kemampuan berfikir kreatif, keluasan pengetahuan, kecerdasan emosional, pengalaman, daya juang, sikap positif, keterampilan kerja serta kondisi kesehatan yang baik yang bias dibuktikan atau diperagakan dalam melaksanakan tugas dan tanggung jawab yang dibebankan kepadanya (Yusuf, 2014).Standar Umum dalam Standar Audit Intern Pemerintah Indonesia (AAIPI, 2014) menyatakan Auditor harus mempunyai pendidikan, pengetahuan, keahlian dan keterampilan, pengalaman, serta kompetensi lain yang diperlukan untuk melaksanakan tanggung jawabnya. Pendidikan, pengetahuan, keahlian dan keterampilan, pengalaman, serta kompetensi lain adalah bersifat kolektif yang mengacu pada kemampuan profesional yang diperlukan auditor untuk secara efektif melaksanakan tanggung jawab profesionalnya.

BPK (2007) dalam Standar Pemeriksaan Keuangan Negara menyatakan organisasi pemeriksa mempunyai tanggung jawab untuk meyakinkan bahwa pemeriksaan dilakukan oleh personil yang mempunyai kompetensi profesional dan secara kolektif mempunyai keahlian dan pengetahuan yang memadai.Oleh karena itu, organisasi pemeriksa harus memiliki prosedur rekrutmen, pengangkatan, pengembangan berkelanjutan, dan evaluasi atas pemeriksa untuk membantu organisasi pemeriksa dalam mempertahankan pemeriksa yang memiliki kompetensi yang memadai.Pemeriksa yang melaksanakan pemeriksaan menurut Standar Pemeriksaan harus memelihara kompetensinya melalui pendidikan profesional berkelanjutan. Pimpinan APIP harus yakin bahwa latar belakang pendidikan, kompetensi, dan pengalaman auditor memadai untuk pekerjaan audit yang akan dilaksanakan.

Prinsip-prinsip perilaku dalam PER/04/M.PAN/03/2008 menyatakan Auditor harus memiliki pengetahuan, keahlian, pengalaman dan keterampilan yang diperlukan untuk melaksanakan tugas. Selanjutnya aturan prilaku menyatakan bahwa auditor wajib (a). melaksanakan tugas pengawasan sesuai dengan Standar Audit; (b). terus menerus meningkatkan kemahiran profesi, keefektifan dan kualitas hasil pekerjaan; dan (c). menolak untuk melaksanakan tugas apabila tidak sesuai dengan pengetahuan, keahlian, dan keterampilan yang dimiliki.

Obyektivitas merupakan sikap auditor untuk dapat bertindak adil, tidak terpengaruh oleh hubungan kerjasama dan tidak memihak kepentingan siapapun sehingga auditor dapat diandalkan dan dipercaya. Auditor harus dapat mengungkapkan kondisi sesuai fakta yaitu dengan mengemukakan pendapat apa adanya, tidak mencari-cari kesalahan, mempertahankan kriteria dan menggunakan pikiran yang logis (Harahap, 2014). Obyektifitas berarti tidak memihak dan tidak berat sebelah dalam semua hal yang berkaitan dengan penugasan (Indratiningsih, 2015).

Prinsip-prinsip dasar dalam Standar Audit Intern Pemerintah Indonesia (AAIPI, 2014) menyatakanauditor harus memiliki sikap yang netral dan tidak bias serta menghindari konflik kepentingan dalam merencanakan, melaksanakan, dan melaporkan penugasan yang dilakukannya. Auditor harus obyektif dalam melaksanakan audit intern. Prinsip obyektivitas mensyaratkan agar auditor melaksanakan penugasan dengan jujur dan tidak mengompromikan kualitas.Pimpinan APIP tidak diperkenankan menempatkan auditor dalam situasi yang membuat auditor tidak mampu mengambil keputusan berdasarkan pertimbangan profesionalnya.

Pusdiklatwas BPKP (2005), menyatakan obyektifitas sebagai bebasnya seseorang dari pengaruh pandangan subyektif pihak-pihak lain yang berkepentingan, sehingga dapat mengemukaan pendapat menurut apa adanya. Unsur perilaku yang dapat menunjang obyektifitas antara lain (1) dapat diandalkan dan dipercaya, (2) tidak merangkap sebagai panitia tender, kepanitiaan lain dan atau pekerjaan-pekerjaan lain yang merupakan tugas operasional obyek yang diperiksa, (3) Tidak berangkat tugas dengan niat untuk mencari-cari kesalahan orang lain, (4) dapat mempertahankan kriteria dan kebijaksanaan-kebijaksanaan yang resmi, serta (5) dalam bertindak maupun mengambil keputusan didasarkan atas pemikiran yang logis. 
Prinsip-prinsip perilaku dalam PER/04/M.PAN/03/2008 menyatakan Auditor harus menjunjung tinggi ketidakberpihakan profesional dalam mengumpulkan, mengevaluasi, dan memproses data/informasi auditi. Auditor APIP membuat penilaian seimbang atas semua situasi yang relevan dan tidak dipengaruhi oleh kepentingan sendiri atau orang lain dalam mengambil keputusan. Selanjutnya aturan prilaku menyatakan bahwa auditor wajib (a).mengungkapkan semua fakta material yang diketahuinya yang apabila tidak diungkapkan mungkin dapat mengubah pelaporan kegiatan-kegiatan yang diaudit; (b). tidak berpartisipasi dalam kegiatan atau hubungan-hubungan yang mungkin mengganggu atau dianggap mengganggu penilaian yang tidak memihak atau yang mungkin menyebabkan terjadinya benturan kepentingan; (c). menolak suatu pemberian dari auditi yang terkait dengan keputusan maupun pertimbangan profesionalnya.

Pengalaman kerja auditor merupakan sikap auditor yang semakin lama menjadi auditor akan membuat auditor memiliki kemampuan untuk memperoleh informasi yang relevan, mendeteksi kesalahan dan mencari penyebab munculnya kesalahan. Banyaknya tugas pemeriksaan yang dilakukan membuat auditor lebih teliti, dapat belajar dari kesalahan yang lalu dan cepat dalam menyelesaikan tugas (Ilat dkk, 2015).Robyn dan Peter (2008) dalam Futri dan Juliarsa (2014) mengemukakan bahwa tugas berbasis pengalaman yang diperoleh dapat meningkatkan kinerja seseorang dalam melaksanakan tugas.

Standar umum dalam Standar Profesional Akuntan Publik menyatakan auditor disyaratkan memiliki pengalaman kerja yang cukup dalam profesi yang ditekuninya, serta dituntut untuk memenuhi kualifikasi teknis dan berpengalaman dalam bidang industri yang digeluti kliennya.Christiawan (2002) dalam Sukriah dkk. (2009) mengemukakan pengalaman akuntan publik akan terus meningkat seiring dengan makin banyaknya audit yang dilakukan serta kompleksitas transaksi keuangan perusahaan yang diaudit sehingga akan menambah dan memperluas pengetahuannya di bidang akuntansi dan auditing .

Marinus (1997) dalam Sukriah dkk.(2009) menyatakan bahwa secara spesifik pengalaman dapat diukur dengan rentang waktu yang telah digunakan terhadap suatu pekerjaan atau tugas (job).Purnamasari (2005) dalam Sukriah dkk. (2009) memberikan kesimpulan bahwa seorang karyawan yang memiliki pengalaman kerja yang tinggi akan memiliki keunggulan dalam beberapa hal diantaranya: 1) mendeteksi kesalahan, 2) memahami kesalahan dan 3) mencari penyebab munculnya kesalahan.

Pengalaman kerja terkait dengan kompetensi. Audit harus dilaksanakan oleh sebuah tim yang secara kolektif harus mempunyai keahlian yang diperlukan untuk melaksanakan audit kinerja. Oleh karena itu, pimpinan APIP harus mengalokasikan auditor yang mempunyai latar belakang pendidikan formal dan pengalaman sesuai dengan kebutuhan audit (PER/05/M.PAN/03/2008, standar nomor 3010).

\section{Metode Penelitian}

Penelitian ini merupakan jenis penelitian kuantitatif yang bertujuan memberikan bukti empiris pengaruh kompetensi $\left(\mathrm{X}_{1}\right)$, obyektivitas $\left(\mathrm{X}_{2}\right)$, dan pengalaman kerja $\left(\mathrm{X}_{3}\right)$ sebagai variabel independen terhadap kualitas hasil audit sebagai variabel dependen.Teknik analisis yang digunakan adalah analisis regresi linear berganda.

Penelitian ini dilakukan pada Perwakilan BPKP Provinsi Sulawesi Utara.Populasi yang digunakan adalah seluruh pegawai yang bekerja pada Perwakilan BPKP Provinsi Sulawesi Utara yang berjumlah 117 orang pegawai.Teknik pengambilan sampel dalam penelitian ini dilakukan secara purpossive sampling.Berdasarkan kriteria yang telah ditetapkan, sampel yang diambil berjumlah 81 orang.

Kompetensi diukur dengan indicator pengetahuan dan keahlian dengan menggunakan 8 (delapan) pernyataan.Obyektivitas kerja diukur dengan indikator bebas dari benturan kepentingan dan pengungkapan sesuai kondisi fakta, dengan menggunakan 8 (delapan) pernyataan.Pengalaman kerja diukur dengan indikator lamanya bekerja sebagai auditor, dan banyaknya tugas pemeriksa dengan menggunakan 8 (delapan) pernyataan. Kualitas hasil audit diukur dengan indikator kesesuaian pemeriksaan dengan standar audit dan kualitas laporan hasil pemeriksaan dengan menggunakan 10 (sepuluh) pernyataan. Masing-masing item pernyataan tersebut kemudian diukur dengan menggunakan Skala Likert 5 point.

\section{Hasil dan Pembahasan}

Data dalam penelitian ini data primer dikumpulkan dengan cara menyebarkan kuesioner langsung kepada 81 responden. Dari jumlah yang disebarkan tersebut terkumpul sebanyak 76 kuesioner.

Untuk mendapatkan kualitas data dari suatu instrument telah dilakukan uji validitas dan reliabilitas. Pengujian validitas dalam penelitian ini menggunakan Pearson Correlation yaitu dengan cara menghitung korelasi antara skor masing-masing butir pernyataan dengan skor total. Jika korelasi antara skor masing-masing butir pernyataan dengan skor total mempunyai tingkat signifikansi $<0,05$, maka butir pernyataan tersebut dinyatakan valid dan sebaliknya. Hasil Pengujian item pernyataan dari variabel kompetensi, obyektivitas, dan pengalaman kerja memiliki kriteria valid dengan nilai signifikansi $<0,05$. Hal ini berarti semua item pernyataan yang digunakan dalam penelitian ini mampu diungkapkan dalam kuesioner tersebut.

Pengujian reliabilitas dilakukan menggunakan teknik Cronbach Alpha. Suatu instrumen dapat dikatakan reliabel bila memiliki koefisien keandalan atau Cronbach Alpha $\geq 0,60$. Hasil pengujian reliabilitas dalam penelitian ini menunjukkan nilai Cronbach's Alpha untuk variabel kompetensi sebesar 0,765; obyektivitas sebesar 0,799; pengalaman kerja sebesar 0,865; dan kualitas hasil audit sebesar 0,888. Dengan demikian dapat disimpulkan bahwa pernyataan dalam kuesioner ini reliable karena memiliki nilai Cronbach's Alpha $>0,60$. Hal 
ini menunjukkan bahwa apabila pernyataan diajukan kembali akan diperoleh jawaban yang relatif sama dengan jawaban sebelumnya.

Uji normalitas dilakukan untuk mengetahui data berdistribusi normal.Uji normalitas dalam penelitian ini dengan menggunakan grafik P-Plot SPSS.Melalui grafik P-Plot dapat dinilai dari titik-titik penyebaran disekitar garis diagonal apakah searah dan mengikuti garis diagonal.Berdasarkan uji normalitas dengan grafik P-Plot SPSS, didapatkan bahwa titik data menyebar di sekitar garis diagonal dan penyebaran titik-titik data searah mengikuti garis diagonal.Dengan demikian model regresi telah memenuhi asumsi normalitas.

Pengujian multikolinieritas dilakukan untuk melihat apakah pada model regresi ditemukan adanya korelasi antara variabel independen.Cara mendeteksinya adalah dengan melihat nilai tolerance dan nilai Variance Inflation Factor (VIF). Jika nilai VIF $<10$ dan tolerance $>0,1$ maka variabel independen terbebas dari persoalan multikolinieritas. Hasil uji SPSS menunjukkan bahwa semua nilai tolerance $>0,1$ dan nilai VIF $<10$. Hal ini menunjukkan bahwa semua variabel independen terbebas dari multikolinieritas.

Uji heterokedastisitas dilakukan untuk mengetahui apakah dalam sebuah model regresi terjadi ketidaksamaan varians dari residual suatu pengamatan ke pengamatan lain. Ada tidaknya heteroskedastisitas dapat ditentukan dengan melihat grafik plot antara nilai prediksi variabel terikat dengan residual. Jika grafik plot menunjukkan suatu pola titik yang bergelombang atau melebar kemudian menyempit, maka dapat disimpulkan bahwa telah terjadi heteroskedastisitas. Namun jika tidak ada pola yang jelas, yaitu serat titik-titik menyebar di atas dan di bawah angka 0 pada sumbu Y, maka tidak terjadi heteroskedastisitas.Hasil uji menunjukkan bahwa pada scatterplot, titik-titik yang ada tidak membentuk sebuah pola namun menyebar, sehingga dapat disimpulkan bahwa dalam penelitian tidak terjadi heterokedastisitas.

Pengujian uji asumsi klasik dalam penelitian ini telah dipenuhi untuk selanjutnya dilakukan pengujian analisis regresi berganda.Model regresi berganda dalam penelitian ini adalah untuk menguji pengaruh kompetensi $\left(\mathrm{X}_{1}\right)$, obyektivitas $\left(\mathrm{X}_{2}\right)$, dan pengalaman kerja $\left(\mathrm{X}_{3}\right)$ terhadap kualitas hasil audit $(\mathrm{Y})$.

Hasil analisis regresi linear berganda pada tabel 1.

Tabel 1. Hasil Regresi Berganda

\begin{tabular}{|c|c|c|c|c|c|c|}
\hline \multicolumn{7}{|c|}{ Coefficients $^{\mathrm{a}}$} \\
\hline & \multirow[t]{2}{*}{ Model } & \multicolumn{2}{|c|}{$\begin{array}{c}\text { Unstandardized } \\
\text { Coefficients }\end{array}$} & \multirow{2}{*}{$\begin{array}{c}\text { Standardized } \\
\text { Coefficients } \\
\text { Beta } \\
\end{array}$} & \multirow[t]{2}{*}{$t$} & \multirow[t]{2}{*}{ Sig. } \\
\hline & & $\mathrm{B}$ & Std. Error & & & \\
\hline \multirow{4}{*}{1} & (Constant) & 0,443 & 0,380 & & 1,164 & 0,248 \\
\hline & Kompetensi & 0,150 & 0,074 & 0,160 & 2,045 & 0,044 \\
\hline & Obyektivitas & 0,368 & 0,105 & 0,347 & 3,511 & 0,001 \\
\hline & Pengalaman kerja & 0,402 & 0,090 & 0,437 & 4,450 & 0,000 \\
\hline
\end{tabular}

Sumber: Hasil Olah data dengan SPSS, 2017.

Berdasarkan tabel 1, diperoleh persamaan regresi berganda sebagai berikut:

$\mathrm{Y}=\mathbf{0 , 4 4 3}+\mathbf{0 , 1 5 0 \times 1}+\mathbf{0 , 3 6 8 \times 2}+\mathbf{0 , 4 0 2 X 3}+\mathrm{e}$

Persamaan regresi berganda di atas dapat dijelaskan sebagai berikut.

1. Kualitas hasil audit (Y) berhubungan positif atau searah dengan kompetensi (X1), obyektivitas (X2), dan pengalaman kerja etika (X3).

2. Model penelitiannya untuk kompetensi menunjukkan bahwa kompetensi memiliki pengaruh positif terhadap kualitas hasil audit dilihat dari nilai koefisien regresi sebesar 0,150. Hal ini menunjukan bahwa semakin baiknya kompetensi maka kualitas hasil audit semakin baik.

3. Model penelitian untuk obyektivitas menunjukkan bahwa obyektivitas memiliki pengaruh positif terhadap kualitas hasil audit dilihat dari nilai koefisien regresi sebesar 0,368. Hal ini menunjukkan bahwa dengan obyektivitas yang tinggi maka kualitas hasil audit semakin baik.

4. Model penelitiannya untuk pengalaman kerja memiliki pengaruh positif terhadap kualitas hasil audit dilihat dari nilai koefisien regresi sebesar 0,402. Hal ini menunjukkan bahwa dengan pengalaman kerja yang baik maka akan menunjang kualitas hasil audit

Pengujian hipotesis secara parsial dilakukan melalui uji t untuk mengetahui besarnya pengaruh masingmasing variabel independen secara individual terhadap variabel dependen. Hasil uji t ini pada output SPSS 20 


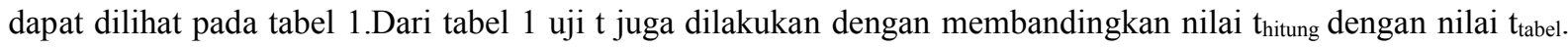
Nilai $t_{\text {hitung }}$ diperoleh dari hasil perhitungan SPSS sedangkan $\mathrm{t}_{\text {tabel }}$ diperoleh dari tabel distribusi $\mathrm{t}$ dicari pada $\mathrm{a}=$ $5 \%: 2=2,5 \%$ (uji 2 sisi) dengan derajat kebebasan (df) n-k-1 atau 76-3-1 = 72. Dengan pengujian 2 sisi (signifikansi $=0,025)$ hasil diperoleh untuk $\mathrm{t}_{\text {tabel }}$ sebesar 1,40 , sehingga:

a. Jika $t_{\text {hitung }}>1,40$ maka Ha diterima dan $\mathrm{H} 0$ ditolak.

b. Jika $t_{\text {hitung }}<1,40$ maka Ha ditolak dan $\mathrm{H} 0$ diterima.

Untuk mengetahui ada tidaknya pengaruh masing-masing variabel independen secara individual terhadap variabel dependen, dapat juga dilakukan dengan membandingkan p-value pada kolom Sig. dengan tingkat signifikansi yang digunakan sebesar 0,05 .

a. Jika p-value $<0,05$ maka Ha diterima dan $\mathrm{H} 0$ ditolak

b. Jika p-value $>0,05$ maka Ha ditolak dan $\mathrm{H0}$ diterima

Penjelasan dari hasil uji parsial adalah sebagai berikut:

1. Pengaruh kompetensi terhadap kualitas hasil audit. Dari tabel 1 dapat dilihat bahwa:

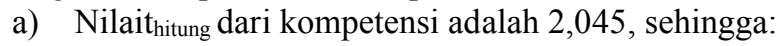

$$
\mathrm{t}_{\text {hitung }}=2,045>\mathrm{t}_{\text {tabel }}=1,40
$$

b) Signifikansi dari variabel kompetensi adalah sebesar $0,044<0,05$.

c) Hal ini menunjukkan bahwa $\mathrm{Ha}_{1}$ diterima dan $\mathrm{H}_{1}$ ditolak, sehingga terbukti bahwa kompetensi berpengaruh positif dan signifikan terhadap kualitas hasil audit.

2. Pengaruh obyektivitas terhadap kualitas hasil audit. Dari tabel 1 dapat dilihat bahwa:

a) Nilai $t_{\text {hitung }}$ dari variabel obyektivitas adalah $=3,511$, sehingga:

$$
t_{\text {hitung }}=3,511>t_{\text {tabel }}=1,40
$$

b) Signifikansi dari variabel obyektivitas adalah sebesar $0,001<0,05$.

c) Hal ini menunjukkan bahwa Ha2 diterima dan H02 ditolak, sehingga terbukti bahwa obyektivitas berpengaruh positif dan signifikan terhadap kualitas hasil audit.

3. Pengaruh pengalaman kerja terhadap kualitas hasil audit. Dari tabel 1 dapat dilihat bahwa:

a) Nilai $t_{\text {hitung }}$ dari variabel pengalaman kerja adalah 4,450, sehingga:

$$
t_{\text {hitung }}=4,450>\mathrm{t}_{\text {tabel }}=1,40
$$

b) Signifikansi dari variabel pengalaman kerja adalah sebesar $0,00<0,05$.

c) Hal ini menunjukkan bahwa $\mathrm{Ha}_{3}$ diterima dan $\mathrm{HO}_{3}$ ditolak, sehingga terbukti bahwa pengalaman kerja berpengaruh positif dan signifikan terhadap kualitas hasil audit.

Uji koefisien determinasi dalam regresi linear berganda, untuk regresi dengan lebih dari dua variabel bebas digunakan adjusted R2 sebagai koefisien determinasi. Berdasarkan hasil uji, nilai adjusted R2 adalah 0,62 yang artinya kualitas hasil audit sebesar $62 \%$ dipengaruhi oleh kompetensi, obyektivitas, dan pengalaman kerja sedangkan sisanya $38 \%$ dipengaruhi oleh faktor lain di luar penelitian ini.

\section{Pengaruh kompetensi terhadap kualitas hasil audit}

Hasil Pengujian hipotesis pertama menunjukan bahwa nilai statistik thitung dari kompetensi adalah 2,045 sehingga: $t_{\text {hitung }}=2,045>\mathrm{t}_{\text {tabel }}=1,40$ dan nilai statistik pada tabel 1 dapat dilihat bahwa variabel kompetensi (X1) memiliki nilai signifikan 0,044, yang berarti nilai ini lebih kecil dari 0,05. Berdasarkan hal tersebut dapat simpulkan bahwa variabel kompetensi berpengaruh positif dan signifikan secara statistik terhadap kualitas hasil audit pada Perwakilan BPKP Provinsi Sulawesi Utara, dengan demikian hipotesis pertama diterima.

Hasil penelitian ini sesuai dengan Pernyataan Standar Umum dalam Standar Audit Intern Pemerintah Indonesia (AAIPI, 2014) menyatakan Auditor harus mempunyai pendidikan, pengetahuan, keahlian dan keterampilan, pengalaman, serta kompetensi lain yang diperlukan untuk melaksanakan tanggung jawabnya. Pendidikan, pengetahuan, keahlian dan keterampilan, pengalaman, serta kompetensi lain adalah bersifat kolektif yang mengacu pada kemampuan profesional yang diperlukan auditor untuk secara efektif melaksanakan tanggung jawab profesionalnya.

Selain itu, BPK (2007) dalam Standar Pemeriksaan Keuangan Negara menyatakan organisasi pemeriksa mempunyai tanggung jawab untuk meyakinkan bahwa pemeriksaan dilakukan oleh personil yang mempunyai kompetensi profesional dan secara kolektif mempunyai keahlian dan pengetahuan yang memadai.Pemeriksa yang melaksanakan pemeriksaan menurut standar pemeriksaan harus memelihara kompetensinya melalui pendidikan profesional berkelanjutan.Prinsip-prinsip perilaku dalam PER/04/M.PAN/03/2008 menyatakan Auditor harus memiliki pengetahuan, keahlian, pengalaman dan keterampilan yang diperlukan untuk melaksanakan tugas.

Hasil penelitian ini mendukung teori sikap dan perilaku dikembangkan oleh Triandis (1971), yang dipandang sebagai teori yang dapat mendasari untuk menjelaskan sikap dan perilaku. Teori tersebut menyatakan, bahwa perilaku ditentukan untuk apa orang-orang ingin lakukan (sikap), apa yang mereka pikirkan akan mereka lakukan (aturan-aturan sosial), apa yang mereka bisa lakukan (kebiasaan) dan dengan konsekuensi perilaku yang mereka pikirkan. Sikap adalah keadaan dalam diri manusia yang menggerakan untuk bertindak, menyertai manusia dengan perasaan-perasaan tertentu dalam menanggapi objek yang terbentuk atas dasar pegalaman- 
pengalaman.Auditor harus kompeten, dalam arti harus memiliki pengetahuan, keahlian, pengalaman dan keterampilan yang diperlukan untuk melaksanakan tugas.

Penelitian ini juga mendukung penelitian sebelumnya yang dilakukan Sukriah (2009) yang menyatakan kompetensi berpengaruh secara positif terhadap kualitas audit. Hasil penelitian ini juga mendukung hasil penelitian yang dilakukan Harahap (2015), Furiady dan Kurnia (2015) dan Bouhawia dkk (2015), namun tidak sejalan dengan penelitan Kovinna dan Betri (2014) yang menyatakan kompetensi tidak berpengaruh signifikan terhadap kulaitas hasil audit.

\section{Pengaruh obyektivitas terhadap kualitas hasil audit}

Hasil Pengujian hipotesis kedua menunjukan bahwa nilai statistik thitung dari obyektivitas adalah 3,511 sehingga: $t_{\text {hitung }}=3,511>t_{\text {tabel }}=1,40$ dan nilai statistik pada tabel 1 dapat dilihat bahwa variabel obyektivitas (X2) memiliki nilai signifikan 0,001, yang berarti nilai ini lebih kecil dari 0,05. Berdasarkan hal tersebut dapat simpulkan bahwa variabel obyektivitas berpengaruh positif dan signifikan secara statistik terhadap kualitas hasil audit pada Perwakilan BPKP Provinsi Sulawesi Utara, dengan demikian hipotesis kedua diterima.

Hasil penelitian ini sesuai dengan prinsip-prinsip dasar dalam Standar Audit Intern Pemerintah Indonesia, Prinsip-prinsip perilaku dalam PER/04/M.PAN/03/2008 dan Standar umum audit menurut Peraturan Menteri Negara Pendayagunaan Aparatur Negara nomor PER/05/M.PAN/03/2008. Standar Audit Intern Pemerintah Indonesia (AAIPI, 2014) menyatakan Auditor harus memiliki sikap yang netral dan tidak bias serta menghindari konflik kepentingan dalam merencanakan, melaksanakan, dan melaporkan penugasan yang dilakukannya. Auditor harus objektif dalam melaksanakan audit intern. Prinsip obyektivitas mensyaratkan agar auditor melaksanakan penugasan dengan jujur dan tidak mengompromikan kualitas.Pimpinan APIP tidak diperkenankan menempatkan auditor dalam situasi yang membuat auditor tidak mampu mengambil keputusan berdasarkan pertimbangan profesionalnya.

Prinsip-prinsip perilaku dalam PER/04/M.PAN/03/2008 menyatakan Auditor harus menjunjung tinggi ketidakberpihakan profesional dalam mengumpulkan, mengevaluasi, dan memproses data/informasi auditi. Auditor APIP membuat penilaian seimbang atas semua situasi yang relevan dan tidak dipengaruhi oleh kepentingan sendiri atau orang lain dalam mengambil keputusan. Standar umum audit menurut Peraturan Menteri Negara Pendayagunaan Aparatur Negara nomor PER/05/M.PAN/03/2008, menyatkan bahwa Auditor harus memiliki sikap yang netral dan tidak bias serta menghindari konflik kepentingan dalam merencanakan, melaksanakan dan melaporkan pekerjaan yang dilakukannya (standar nomor 2120).

Hasil penelitian ini mendukung teori atribusi, menurut Heider (2006) yang menjelaskan tentang perilaku seseorang. Teori atribusi menjelaskan mengenai proses bagaimana kita menentukan penyebab dan motif tentang perilaku seseorang. Teori ini mengacu tentang bagaimana seseorang menjelaskan penyebab perilaku orang lain atau dirinya sendiri yang akan ditentukan apakah dari internal misalnya sifat, karakter, sikap ataupun eksternal misalnya tekanan situasi atau keadaan tertentu yang akan memberikan pengaruh terhadap perilaku individu. Auditor harus memiliki sikap yang netral dan tidak bias serta menghindari konflik kepentingan dalam merencanakan, melaksanakan, dan melaporkan penugasan yang dilakukannya. Auditor harus obyektif dalam melaksanakan audit.Prinsip obyektivitas mensyaratkan agar auditor melaksanakan penugasan dengan jujur dan tidak mengompromikan kualitas.

Hasil penelitian ini mendukung penelitian Ilat (2015) yang berjudul Pengaruh, Obyektifitas, Pengalaman Kerja, Pengetahuan, Serta Integritas Auditor Terhadap Kualitas Hasil Audit di Lingkungan Pemerintah Daerah Provinsi Sulawesi Utara. Hasil penelitian menunjukkan bahwa obyektivitas berpengaruh secara positif terhadap kualitas audit. Semakin tinggi tingkat obyektivitas auditor, maka semakin baik kualitas hasil pemeriksaannya. Hasil penelitian ini juga mendukung hasil penelitian yang dilakukan Mabruri dan Winarna (2010), Sukriah (2009) Harahap (2015) dan Furiady dan Kurnia (2015) yang menyatakan ada pengaruh positif obyektivitas auditor terhadap kualitas audit.

\section{Pengaruh pengalaman kerja terhadap kualitas hasil audit}

Hasil Pengujian hipotesis ketiga menunjukan bahwa nilai statistik thitung dari pengalaman kerja adalah 4,450 sehingga: thitung $=4,450>$ ttabel $=1,40$ dan nilai statistik pada tabel 5.19 dapat dilihat bahwa variabel pengalaman kerja (X3) memiliki nilai signifikan 0,00, yang berarti nilai ini lebih kecil dari 0,05 . Berdasarkan hal tersebut dapat simpulkan bahwa variabel pengalaman kerja berpengaruh positif dan signifikan secara statistik terhadap kualitas hasil audit pada Perwakilan BPKP Provinsi Sulawesi Utara, dengan demikian hipotesis ketiga diterima.

Hasil penelitian ini sesuai dengan Standar umum dalam Standar Profesional Akuntan Publik menyatakan auditor disyaratkan memiliki pengalaman kerja yang cukup dalam profesi yang ditekuninya, serta dituntut untuk memenuhi kualifikasi teknis dan berpengalaman dalam bidang industri yang digeluti kliennya. Standar umum audit menurut Peraturan Menteri Negara Pendayagunaan Aparatur Negara nomor PER/05/M.PAN/03/2008. Pengalaman kerja terkait dengan kompetensi. Audit harus dilaksanakan oleh sebuah tim yang secara kolektif harus mempunyai keahlian yang diperlukan untuk melaksanakan audit kinerja. Oleh karena itu, pimpinan APIP harus mengalokasikan auditor yang mempunyai latar belakang pendidikan formal dan pengalaman sesuai dengan kebutuhan audit.. 
Hasil penelitian ini mendukung penelitian Wandita dkk.(2014) yang berjudul Pengaruh Pengetahuan, Pengalaman Kerja Audit, Dan Akuntabilitas Terhadap Kualitas Hasil Kerja Auditor Internal. Hasil penelitian menunjukkan bahwa pengalaman kerja berpengaruh secara positif terhadap kualitas audit. Semakin berpengalaman seorang auditor, maka semakin baik kualitas hasil audit yang dihasilkannya.Hasil penelitian ini juga mendukung hasil penelitian yang dilakukan Mabruri dan Winarna (2010) Sukriah (2009), Bouhawia dkk.(2015) dan Usman (2016).

Hasil penelitian ini tidak sesuai dengan penelitian yang dilakukan oleh Ilat (2015), yang memberikan penjelasan bahwa variabel pengalaman kerja berpengaruh negatif terhadap kualitas hasil audit. Hasil penelitian Furiady dan Kurnia (2015) dan Kovinna dan Betri (2014) juga menyatakan pengalaman kerja tidak berpengaruh pada kualitas hasil audit.

\section{Kesimpulan dan Saran}

Hasil Penelitian menunjukkan bahwa:

1) Kompetensi berpengaruh positif dan signifikan secara statistik terhadap kualitas hasil audit. Hasil ini memberi indikasi bahwa semakin tinggi tingkat kompetensi yang dimiliki auditor, maka semakin meningkat atau semakin baik kualitas hasil audit yang dihasilkan;

2) Obyektivitas berpengaruh positif dan signifikan secara statistik terhadap kualitas hasil audit. Hasil ini memberi menunjukkan bahwa semakin obyektif auditor dalam melaksanakan pemeriksaan, maka akan semakin tinggi kualitas hasil audit yang dihasilkan;

3) Pengalaman kerja berpengaruh positif dan signifikan secara statistik terhadap kualitas hasil audit. Hasil ini memberi indikasi bahwa semakin berpengalaman seorang auditor, maka semakin baik kualitas hasil audit yang dihasilkannya.

Berdasarkan hasil penelitian yang dilakukan adapun saran yang dapat diberikan sebagai berikut:

1) Disarankan bagi auditor Perwakilan BPKP Provinsi Sulawesi Utara untuk meningkatkan kompetensi yang dimiliki agar semakin meningkat atau semakin baik kualitas hasil audit yang dihasilkan;

2) Auditor Perwakilan BPKP Provinsi Sulawesi Utara diharapkan meningkatkan obyektivitasnya dalam melaksanakan audit, sehingga semakin baik kualitas hasil pemeriksaannya;

3) Auditor Perwakilan BPKP Provinsi Sulawesi Utara sebaiknya meningkatkan pengalaman dalam melaksanakan audit sehingga menghasilkan audit yang berkualitas;

4) Dalam penelitian ini variabel independen yang diteliti yaitu kompetensi, obyektivitas, dan pengalaman kerja berpengaruh terhadap variabel kualitas hasil audit sebesar $62 \%$ berarti bahwa ada pengaruh sebesar 38\% dari variabel-variabel lain diluar penelitian ini. Untuk itu perlu adanya penelitian lebih lanjut tentang faktor-faktor yang mempengaruhi kualitas hasil audit, misalnya profesionalisme, etika auditor, integritas, tingkat etos kerja, kebijakan pemerintah dan sebagainya.

\section{Daftar Pustaka}

Asosiasi Auditor Intern Pemerintah Indonesia (AAIPI).2014. Standar Audit Intern Pemerintah Indonesia. Jakarta.

Bouhawia, Mohammed.S., Gugus Irianto, dan Zaki Baridwan. 2015. The Effect of Working Experience, Integrity, Competence, and Organizational Commitment on Audit Quality (Survey State Owned Companies In Libya). IOSR Journal of Economics and Finance (IOSR-JEF) e-ISSN: 2321-5933, p-ISSN: 23215925.Volume 6, Issue 4. Ver. II (Jul. - Aug. 2015), PP 60-67.

BPKP. 2008. Aturan Perilaku Pegawai BPKP. Jakarta.

Furiadi, Olivia, dan Ratnawati Kurnia. 2015.The Effect of Work Experiences, Competency, Motivation, Accountability, and Objectivity Toward Audit Quality. Procedia - Social and Behavioral Sciences 211 ( 2015 ) 328 - 335, 2nd Global conference of Business and Social Science-2015, GCBSS-2015, 17-18 September, Bali, Indonesia.

Futri, Putu Septiani dan Gede Juliarsa. 2014. Pengaruh Independensi, Profesionalisme, Tingkat Pendidikan, Etika Profesi, Pengalaman, dan Kepuasan Kerja Auditor Terhadap Kualitas Audit Pada Kantor Akuntan Publik di Bali. E-Jurnal Akuntansi Universitas Udayana 8.1 (2014):41-58.

Harahap, Lukman. 2015. Pengaruh Kompetensi, Independensi, Objektivitas dan Sensitivitas Etika Profesi Terhadap Kualitas Hasil Audit (Studi Kasus Pada Auditor BPKP Daerah Istimewa Yogyakarta). Jurnal.Universitas Negeri Yogyakarta.

Heider, Fritz. 1958. The Psychology of Interpersonal Relations. New York: Wiley.

Ilat Ventje, David P.E. Saerang, Heince R.N. Wokas. 2015. Pengaruh Independensi, Obyektifitas, Pengalaman Kerja, Pengetahuan, Serta Integritas Auditor Terhadap Kualitas Hasil Audit di Lingkungan Pemerintah Daerah Provinsi Sulawesi Utara. Jurnal. Universitas Sam Ratulangi.

Indratiningsih, Wiwit. 2015. Analisis Faktor-Faktor Yang Mempengaruhi Kualitas Hasil Audit di Lingkungan Pemerintah Daerah. Jurnal.Universitas Muhammadiyah Surakarta. 
Kovinna, Fransiska dan Betri. 2014. Pengaruh Independensi, Pengalaman Kerja, ompetensi, dan Etika Auditor terhadap Kualitas Audit (Studi Kasus pada Kantor Akuntan Publik di Kota Palembang).Journal.STIE MDP.

Mabruri, Havidz, Jaka Winarna. 2010. Analisis Faktor-Faktor Yang Mempengaruhi Kualitas Hasil Audit di Lingkungan Pemerintah Daerah. Simposium Nasional Akuntansi XIII Purwokerto.

Peraturan Menteri Negara Pendayagunaan Aparatur Negara Nomor:PER/04.PAN/03/2008 tentang Kode Etik Aparat Pengawasan Intern Pemerintah. Jakarta.

Peraturan Menteri Negara Pendayagunaan Aparatur Negara Nomor:PER/05.PAN/03/2008 tentang Standar Audit Aparat Pengawasan Intern Pemerintah. Jakarta.

Peraturan Pemerintah nomor 60 tahun 2008 tentang Sistem Pengendalian Intern Pemerintah (SPIP). Jakarta.

Peraturan Pemerintah Nomor 71 tahun 2010 tentang Standar Akuntansi Pemerintahan. Jakarta.

Peraturan Presiden Republik Indonesia Nomor 192 Tahun 2014 tentangBadan Pengawasan Keuangan dan Pembangunan. Jakarta.

Pusdiklatwas BPKP. 2008. Kode Etik dan Standar Audit. Edisi ke lima. Ciawi.

Rai, A. 2008.Audit Kinerja Pada Sektor Publik. Penerbit Salemba Empat.

Sukriah Ika, Akram, Biana Adha Inapty. 2009. Pengaruh Pengalaman Kerja, Independensi, Obyektifitas, Integritas dan Kompetensi Terhadap Kualitas Hasil Pemeriksaan. Simposium Nasional Akuntansi XII. Palembang.

Triandis, H.C. 1971. Attitudes and Attitudes Change. Jhon Waley and Sons, Inc, New York.

Undang-undang Nomor 17 Tahun 2003 tentang Keuangan Negara. Jakarta.

Undang-undang Nomor 1 Tahun 2004 tentang Perbendaharaan Negara. Jakarta.

Undang-undang Nomor 15 Tahun 2004 tentang Pemeriksaan Pengelolaan dan Pertanggungjawaban Keuangan Negara. Jakarta.

Usman. 2016. Effect of Experience and Accountability on the Quality of Internal Audit. International Journal of Scientific \& Technology Research Volume 5, Issue 03, March 2016.

Wandita, Ni Luh Putu Tri Angga, Gede Adi Yunita, dan Nyoman Ari Surya Darmawan.2014. Pengaruh Pengetahuan, Pengalaman Kerja Audit, dan Akuntabilitas Terhadap Kualitas Hasil Kerja Auditor Internal.e-Journal Universitas Pendidikan Ganesha Jurusan Akuntansi Volume 2 No. 1 Tahun 2014.

Yusuf, M. 2014. Pengaruh Kompetensi, Objektivitas dan Integritas Auditor Terhadap Kualitas Hasil Kerja Auditor (Studi Empiris pada Auditor BPKP Provinsi Riau).Jurnal.Universitas Negeri Padang. 